\title{
FUTURE PERSPECTIVE AND WORK READINESS ON STUDENTS
}

\author{
Ali Ridho, Ariska Dwi Siswanti \\ Faculty of Psychology, Universitas Islam Negeri Maulana Malik Ibrahim \\ Jl. Gajayana 50, Malang, East Java, Indonesia -65144 \\ aliridho@uin-malang.ac.id
}

\begin{abstract}
This study aims to prove that the future perspective (FP) can be a good predictor of work readiness (WR) among college students. This study used the correlational method. A total of 90 eighth semester students (60 male, 30 female) from the Faculty of Science and Technology, Psychology, and Tarbiyah of the Universitas Islam Negeri Maulana Malik Ibrahim Malang became participants in this study. Participants' age ranged between 21-25 years $(\mathrm{M}=23.7$ years). This study used the adaptation of future perspective (FP) instruments from Husman and Shell (2008), which consists of 15 items, with $\alpha=0.830$, and the work-readiness adaptation instrument from Cabellero et al. (2011), which consists of 16 items, with $\alpha=0.849$. The researcher analyzed the data with bivariate linear regression. The study suggested a regression coefficient of $\mathrm{B}=0.413$ with $\mathrm{t}(89)=$ $5.314 \mathrm{p}<0.01, \mathrm{r}(88)=0.493 \mathrm{p}<0.01$, and $\mathrm{R}^{2}=0.243$. These results indicate that $\mathrm{FP}$ has a strong relationship with WR, and FP can be a good predictor for WR. Therefore it can be concluded that FP supports the work readiness of students. This study suggests that students should be courageous in choosing meaningful activities to create a strong connection between the performed activities and the proposed career.
\end{abstract}

Keywords: future perspective; work-readiness; college student

\begin{abstract}
Abstrak
Penelitian ini hendak membuktikan apakah perspektif masa depan (PMD) mampu menjadi prediktor yang baik bagi kesiapan bekerja (KBK) pada mahasiswa. Penelitian ini menggunakan metode korelasional, sebanyak 90 mahasiswa semester delapan (60 laki-laki, 30 perempuan) dari Fakultas Sains dan Teknologi, Psikologi, serta Tarbiyah Universitas Islam Negeri Maulana Malik Ibrahim Malang menjadi partisipan. Usia partisipan terentang antara 21-25 tahun $(M=23.7$ tahun). Instrumen pengukuran PMD (15 aitem, $\alpha=0.830)$ diadaptasi dari Husman dan Shell (2008), sedangkan instrumen KBK (16 aitem, $\alpha=0,849)$ diadaptasi dari Cabellero dkk. (2011). Data dianalisis dengan regresi linier bivariat. Penelitian menghasilkan koefisien regresi sebesar $B=$ 0.413 dengan $t(89)=5.314 p<0.01, r(88)=0.493 p<0.01$, dan $R^{2}=0.243$. Selain PMD terbukti mampu menjadi prediktor yang baik terhadap KBK, ditemukan pula aspek keterhubungan berperan besar dalam mendukung kesiapan bekerja mahasiswa. Oleh sebab itu disarankan agar mahasiswa meyakinkan dirinya dalam memilih kegiatan yang bermakna sehingga terbentang koneksi yang kuat antara kegiatan yang sedang dijalankan dengan karier yang dituju.
\end{abstract}

Kata kunci: perspektif masa depan; kesiapan bekerja; mahasiswa

\section{INTRODUCTION}

Work readiness is a critical attribute for students (Hanani \& Sukirno, 2016; Perry, Wallace, \& McCormick, 2016; Yakhina, Yakovlev, Kozhevnikova, Nuretdinova, \& Solovyeva, 2016). The necessity for establishing work-readiness among students is increasing (Cabellero \& Walker, 2010; Daniels \& Brooker, 2014). To be better qualified for a career and face the working world in the future, students should already have a high level of work-readiness in the final semester (Santrock, 2012). Students will have motivation if they have precise goals and ideas for the future. Several studies have shown that the future perspective significantly influences the individuals' motivation (Lens, Paixão, Herrera, \& Grobler, 2012). Individuals with a precise goal about their future are considered capable of responding to a situation and positively 
responding to work readiness, for example, by increasing their skills and understanding in entering the workforce (Pool \& Sewell, 2007).

According to Lang and Carstensen (2002), a future perspective is the individual's perception or idea about the remaining time of his life and the various opportunities and targets available in the future. Future perspective is related to the perception of time, the extent to which individuals perceive goals in the future, connect to the future, project their thoughts in the future, and describe space-time as a factor considered by individuals in making decisions about their future achievement ( Husman \& Shell, 2008). There are two ideas in understanding a future perspective. First is Zimbardo and Boyd's (2015) 's view, which accommodates the whole concept of "time perspective" from Lewin. They define the perspective of time as the overall psychological view of a person towards his future and past. The other view is the opinion of Husman and Lens (1999), who emphasize the present and future and pay less attention to the past. Specifically, Husman and Lens (1999, p. 114) define future perspectives as the degree to which the chronological future is integrated into the present life-space of an individual through motivational goal-setting processes. In the future perspective framework, time is not a physical thing, but a belief (Shell \& Husman, 2001), which is more psychological in each individual (Husman \& Shell, 2008), and influences present people behavior (Hilpert, Husman, Stump, Kim, Chung, \& Duggan, 2012). Husman and Hilpert (2017) state that a person's thoughts and understanding of the future can be seen based on future goals (self probability in the future); time horizon (the imaginable farthest possible future); and orientation towards the future (belief about the present and future).

Based on the understanding of Husman and Hilpert (2017) and a series of studies from Husman, Brem, Banegas, Duchrow, and Haque (2015), the researcher concludes that there are at least four aspects that need to be considered in constructing the instrument to measure the future perspective. The four aspects are valence, connectedness, distance/extension, and speed. Valence means focusing on future goals, such as valuing and sacrificing for future goals and making important decisions related to those goals. Connectedness means individuals' ability to develop instruments of current activities and connect the activities with future goals. Expansion (extension) means the individuals' ability to project their thoughts and views on the future. Speed means the individual's ability to perceive the speed of time to achieve his future. Future perspective in this study refers to the views of Husman and Shell (2008), considering that this concept illustrates the future that is associated with the present so that it leads to motivational attributes.

According to Cabellero, Walker, and FullerTyszkiewicz (2011), work readiness (WK) is a benchmark that graduates have attitudes and attributes that lead them to ready to work and succeed in the workplace. Meanwhile, Hersey and Blanchard (1996) suggest that work readiness is a level of ability and willingness for someone to complete a particular task. Individuals with work readiness have the expertise, knowledge, understanding, and personality that makes them able to choose and feel comfortable with their work, so they have job satisfaction and ultimately can achieve success (Pool \& Sewell, 2007).

The limited number of studies about future time perspective in Indonesia is the reason for conducting this study. Some existing research (Marliani, 2013; Sersiana, 2013) still requires developing research studies. Research from Grashinta, Istiqomah, and Wiroko (2018), which connected future time perspective with career maturity, is a reference for this research. This study examines the relationship between future perspective and work-readiness. Therefore, this research is the first study in Indonesia 
that examines the relationship between future perspective and work readiness in final year students.

The work-readiness (WR) aspects, according to Cabellero et al. (2011), are:

1) Personal characteristics, in term of individual attitude maturity, include self-resilience, adaptability, selfdirection, self-knowledge, and personal development;

2) organizational acumen refers to individual attitudes in the organization which includes motivation, maturity, organizational awareness, professionalism or work ethics, social responsibility, and attitude to work;

3) work competence refers to attitudes, knowledge, and skills in work which include work motivation, problemsolving, critical thinking, and creative thinking or innovation;

4) social intelligence refers to the attitude of individuals in dealing with social relationships with others in their environment, which includes teamwork, social skills, adaptability, and interpersonal communication skills.

Future perspectives (FP) are assumed to contribute to student work readiness (WR) positively. At least three arguments are supporting the assumption. First is a strong valence towards the future in the form of a particular profession. Students with the expectation of being a teacher, architect, and industrial psychologist will have a secure connection with their desirable profession. There is a tendency that students choose activities that will support the achievements of their expectations in the future. The motivation to master the knowledge and skills needed for the desired professional profile will increase. Second, the energetic projection of thoughts and views on the future will foster greater awareness (mindful).
Furthermore, projections about the future stimulate creativity and innovation to anticipate obstacles and challenges they will confront in the future. Furthermore, someone with a future perspective will develop strong self-resilience, able to adapt, have the right direction, and become a mature person. Finally, a strong relationship between future expectations and work-readiness will motivate students to create instruments of activities that need to be carried out, such as improving the ability to organize, socialize, adapt, and communicate interpersonally.

In several studies, future perspectives have positive contributions to academic motivation (Barnett, Melugin, \& Hernandez, 2018; Lens \& Seginer, 2015), work motivation (Maarel, 2011), and academic achievement (Kooij, Kanfer, Betts, \& Rudolph, 2018). Besides, in school students, future perspective also contributes to the interest and behavior regulation, academic achievement, and persistence in learning (Peetsma \& van der Veen, 2011). In a further study, future perspective in employees contributes to the organization's sense of belonging (Bagrationi \& Thurner, 2020).

The above explanation leads to the research question. The research question is "Can future perspectiv (FP) be a good predictor for work-readiness (WR)?" The research hypothesis is "There is an influence of the future perspective on student work readiness."

\section{METHOD}

\section{Research design}

This study used correlational studies. The independent variable in this study is the future perspective (FP) or Future time Perspective (FTP), while the dependent variable is work-readiness (WR).

\section{Participant}

The data collection was conducted on three faculties at the Universitas Islam Negeri Maulana Malik Ibrahim Malang. The faculties are Science and Technology, 
Psychology, and Tarbiyah. A total of 90 students in the 8th semester (60 male, 30 female) participated in this study. The age of participants ranged between 21-25 years, with an average age of 23.7 years. The sample selection is nonprobability sampling, because, in the 8th semester, they rarely come to campus. The only reason to appear on campus is to get the thesis supervision. Table 1 present the distribution of research subjects.

Table 1.

Participant

\begin{tabular}{clc}
\hline Faculties & Gender & Quantity \\
\hline Science and Technology & Female & 14 \\
& Male & 16 \\
\hline Psychology & Female & 19 \\
& Male & 11 \\
\hline Tarbiyah & Female & 27 \\
& Male & 3 \\
\hline Total Participant & 90 \\
\hline
\end{tabular}

\section{Research Instrument and Data Analysis}

The research data were obtained based on participant responses. The instrument used to measure future perspective is an adaptation of the Future Time Perspective Scale (Husman \& Shell, 2008). Future time Perspective Scale consists of 15 items measuring four aspects, namely: valence, connectedness, expansion, and speed. This study also used the Work Readiness Scale, adapted from Cabellero et al. (2011), to measure work readiness. This scale consists of 16 items, measuring aspects: personal characteristics, organizational acumen, work competence, and social intelligence. Participants were asked to provide response options from strongly disagree to strongly agree, with a score of 1 - 5 strongly. An example of FP items is "I am taking steps today to help realize future goals." While an example of WR scale items is "I am able to work in groups." The Cronbach alpha internal consistency score (reliability) was .830 on the FP scale and .849 on the WR scale.

\section{Data Analysis}

This study used a bivariate regression data analysis technique. The data analysis result shows the magnitude of the correlation, influence, and predictive power of future perspective (FP) on work-readiness (WR). As an additional analysis, an FP difference test was also conducted based on gender and faculty.

\section{RESULTS AND DISCUSSION}

The mean measurement of FP shows scores ranging from $36-72$ with $\mathrm{M}=54.57$ and $\mathrm{SD}$ $=7.67$. At the same time, the WR measurement results show the scores ranging from 46-76 with $\mathrm{M}=61.24$ and $\mathrm{SD}=6.43$. Table 3 shows the correlations between aspects of the FP and WR variables. Table 2 shows the difference in FP mean.

Work-readiness (WR) regression analysis of future perspective (FP) produced a regression coefficient of $\mathrm{B}=0.413$ with $\mathrm{t}(89)=5.314 \mathrm{p}$ $<.01, \mathrm{r}(88)=.493 \mathrm{p}<.01$, and $\mathrm{R}$ squared is .243. The results mean that FP is significantly proven to be a good predictor for WR. Every increase of one FP score point is predicted to increase the WR score of 0.413 points.

Regression analysis and quadratic correlations indicate that students' views of the future contribute significantly to readiness at work. Thus, the hypothesis in this study can be accepted. There is a significant relationship between the perspective of the future (FP) and work readiness (WR) of students. This finding is in line with previous research showing that FP has a role in career decision making (Atanásio, Paixão, \& da Silva, 2013; Walker \& Tracey, 2012), career maturity (Grashinta et al., 2018; Sersiana, 2013), and employability (Froehlich, Beausaert, \& Segers, 2015). Thus, it can be concluded that FP is one of the factors that drive individuals to prepare for the future, especially in the field of work. 
Table 2.

Average Work Readiness (WR) based on Faculty and Gender

\begin{tabular}{ccccc}
\hline Gender & Faculties & $M$ & $S D$ & $N$ \\
\hline Female & Science and Tech. & 62.64 & 8.243 & 14 \\
& Psychology & 62.53 & 5.189 & 19 \\
& Tarbiyah & 58.67 & 6.385 & 27 \\
\cline { 2 - 5 } Male & Total & 60.82 & 6.708 & 60 \\
& Science and Tech. & 63.56 & 4.802 & 16 \\
& Psychology & 61.64 & 7.018 & 11 \\
& Tarbiyah & 56.00 & 1.000 & 3 \\
\cline { 2 - 5 } Total & Total & 62.10 & 5.839 & 30 \\
& Science dan Tech. & 63.13 & 6.527 & 30 \\
& Psychology & 62.60 & 5.821 & 30 \\
& Tarbiyah & 58.40 & 6.106 & 30 \\
\cline { 2 - 5 } & Total & 61.24 & 6.427 & 90 \\
\hline
\end{tabular}

Notes: $M=$ Mean, $S D=$ Standard Deviation, $N=$ Number of Participants

Table 3.

Correlations in Each Aspects

\begin{tabular}{|c|c|c|c|c|c|c|c|}
\hline Scale and Aspects & 1 & 2 & 3 & 4 & 5 & 6 & 7 \\
\hline \multicolumn{8}{|l|}{ FP Scale } \\
\hline 1. valence & 1 & & & & & & \\
\hline 2. connectedness & $.257 *$ & 1 & & & & & \\
\hline 3. expansion (distance) & .120 & $.335 * *$ & 1 & & & & \\
\hline 4. speed & .005 & $.294 * *$ & $.379 * *$ & 1 & & & \\
\hline \multicolumn{8}{|l|}{ WR Scale } \\
\hline $\begin{array}{l}\text { 5. Personal } \\
\text { characteristics }\end{array}$ & .157 & $.527 * *$ & .175 & .148 & 1 & & \\
\hline $\begin{array}{l}\text { 6. organizational } \\
\text { acumen }\end{array}$ & .119 & $.382 * *$ & -.064 & .018 & $.481 * *$ & 1 & \\
\hline 7. work competence & .185 & $.304 * *$ & .174 & $.247 *$ & $.341 * *$ & $.405^{* *}$ & 1 \\
\hline 8. social intelligence & .141 & $.349 * *$ & $.249 *$ & .155 & $.520 * *$ & $.386^{* *}$ & $.482 * *$ \\
\hline
\end{tabular}

Notes: $*=p<.05 ; * *=p<.01$

The process of giving meaning to many activities performed by students, such as learning, discussing the thesis with friends, making a journal's review related to the thesis; will function if the students relate it to the future of work, that is considered since present. The strength of projections for future work will correspond to awareness about the critical value of relevant activities that they are currently undertaking (Eren, 2013) so that these activities will be interpreted as the instrument that supports future goals (Fong \& Kim, 2019).

Student awareness about the relationship between current study activities and career goals will increase the ability of selfadaptation in achieving future goals and be more resilient to face some disruption in completing the study. A strong student's valence in interpreting their activities can affect future careers. The students' valence is the willingness to sacrifice time, energy, and costs, although the benefits of the activity are not yet shortly obvious. The impact, students become more focused on increasing knowledge and developing themselves in the open learning environment (Husman, Hilpert, $\&$ Brem, 2016). By focusing on future goals, students will be able to project their thoughts and views broadly and appreciate their future goals so that they are motivated to complete 
tasks promptly (Shell \& Husman, 2001), and not delay their assignments and work.

Students with high awareness that their nowadays activities will have a significant impact on their future will choose activities that will benefit themselves. Students tend to develop their social skills to build relationships or networks, encourage his/her self to be more confident in making decisions, and experience less anxiety in choosing and carrying out activities for the desirable career (Walker \& Tracey, 2012). In order to improve soft skills, the learning process for students can be strengthened by incorporating elements of affective skills (Bandaranaike \& Willison, 2015), adaptive behaviour (Carvalho, 2015), exchange students (Patterson, Boyd, \& Mnatzaganian, 2017), and project-based learning (Jollands, Jolly, \& Molyneaux, 2012).

An individual's future orientation is subjective. The future orientation can be in the short term or long term can be weeks, months, years, even decades in the future. The farther the individuals' perspective on the future, the easier it will be to interpret the consequences of the instrumental activities being performed by the individual, as well as the incentives that will be received far in the future (Husman \& Shell, 2008). Estimation of nowadays activities impact on their future will also lead to ease in decision making in terms of the earnestness in undergoing their current activities (Siegman, 1961). Therefore, it can be concluded that students will be better prepared to work if they have a further orientation.

Further research exploration data examine the average differences in work-readiness (WR) score. Table 2 displays the mean WR score by gender and faculty. Meanwhile, Figure 1 presents the mean differences.

The Result of variance analysis based on gender is $F(1.88)=0.796$ with $p>.05$. The result shows that there is no significant difference in work-readiness between male and female students. At UIN Maulana Malik Ibrahim Malang, readiness to work for female students is equivalent to male students. The result of the variance analysis by faculty is $F(2.84)=3.448 \mathrm{p}<.05$. The result means that there are significant differences in average scores across the three faculties. The post-hoc test found that significant differences of work-readiness occur among the faculties of Science and Technology vs Tarbiyah ( $\mathrm{p}<.01)$, as well as Psychology vs Tarbiyah ( $\mathrm{p}<.05)$. Meanwhile, in FP score, there was no significant difference found among the faculties ( $p>.05)$.

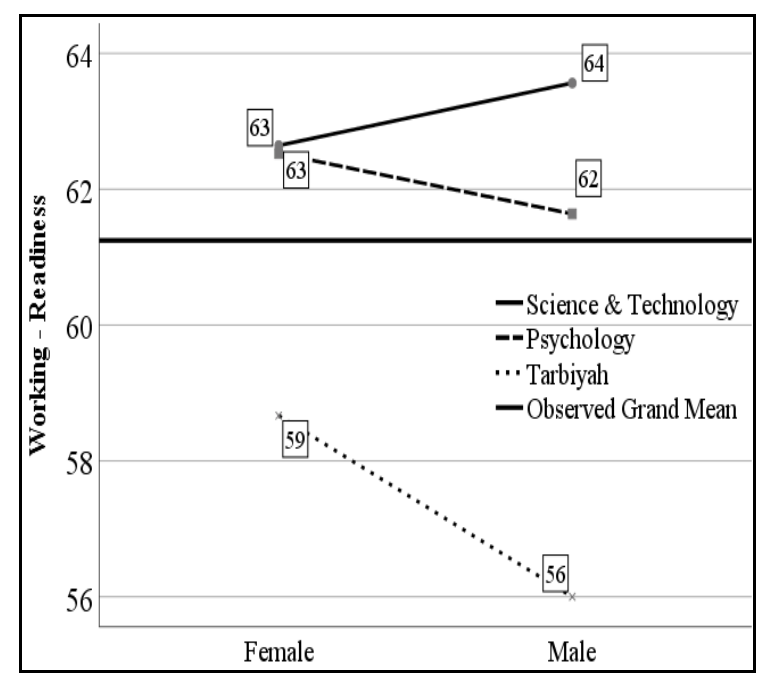

Figure 1. Mean of Working-Readiness Score in Male and Female in each Faculty

Students of the Faculty of Science and Technology and the Faculty of Psychology have a higher score of readiness to work compared to students of the Tarbiyah Faculty. Several factors need to be considered as factors contributing to these differences. The first factor is the new students' admission process. The admission process for the faculty of science and technology and psychology is through the general entrance exam, while for the Tarbiyah Faculty is through the value of religiosity. Second is cultural factors. Lecturers and students at the Faculty of Science and Technology and the Faculty of Psychology have a great diversity in terms of 
professional backgrounds. Besides, the people in these two faculty have more comprehensive networking than lecturers and students at the Faculty of Tarbiyah. Those two factors are assumed can impact the thinking process about the future, mainly in student in the final semester. Students in nonreligious faculties tend to have a perspective that the future must be fought for with a more significant proportion, while students in the religious faculty put more emphasis on external matters and fought for later. In other words, the locus of work readiness is more internal to students in non-religious faculties. In the context of this research, the construct theory of Cabellero et al. (2011) about workreadiness can be a reference for the result of this study. The student in the faculty of science and technology and psychology have higher and greater work-readiness compared to the students in the Tarbiyah faculty.

This research proved the contribution of future perspective to work-readiness. Besides, this study also found a significant correlation between connectedness with all aspects of work-readiness. Thus it can be concluded that connectedness has an essential role in developing the students' work-readiness. The aspect of connectedness explains the extent to which an individual can create instruments of current activity, which connects with his future goals and ideals. Through the strong connectedness between the future and the present, students can regulate themselves and can understand the importance of carrying out their current activities and commit to their activities (Fong \& Kim, 2019). Besides, someone can interpret that current activities and actions are instruments to achieve his career goals in the future.

Furthermore, after this research findings, researchers suggest and make the implication for the student and further study. To all students, it is strongly recommended to see the future in more than ten or twenty years, dream big, raise hope in every activity, and connect the perspective about future by choosing activities to support the big dreams and hopes. Researcher suggests for further research to examine the types of activities and actions that can be capable instruments to contribute to work-readiness.

Some limitations of this study are: (1) the instrument used in this study is a self-report scale with high social desirability, so this instrument increases the possibility of socially desirable responding from the participant; (2) the participants in this study come from the same university, thus the restricted data collection's area can limit the generalizability of the findings. The researchers suggest that further research use the instrument with forced-choices and broaden the area of participants by collaborating with other universities.

\section{CONCLUSION}

The conclusion that can be delivered based on the discussion is that future perspective can predict readiness to work for students. The connectedness aspect plays an essential role in supporting students' work-readiness. Therefore it is suggested that from nowadays students convince themselves in choosing meaningful activities so that there is a secure connection between the activities being carried out with the proposed career.

\section{REFERENCES}

Atanásio, P., Paixão, M. P., \& da Silva, J. T. (2013). The influence of future time perspective in career decision-making: the mediating role of work hope. In M. P. Paixão, J. T. da Silva, V. Ortuño \& P. Corderio (Eds.), International Studies in Time Perspective. De Coimbra: Coimbra University Press.

Bagrationi, K., \& Thurner, T. (2020). Using the future time perspective to analyse resistance to, and readiness for, change. Employee Relations: The International Journal, 42(1), 262-279. doi: 10.1108/ER-04-2018-0113 
Bandaranaike, S., \& Willison, J. (2015). Building capacity for work-readiness: Bridging the cognitive and affective domains. Asia-Pacific Journal of Cooperative Education, 16(3), 223-233.

Barnett, M. D., Melugin, P. R., \& Hernandez, J. (2018). Time Perspective, Intended Academic Engagement, and Academic Performance. Current Psychology, 1-7. doi: 10.1007/s12144-017-9771-9

Cabellero, C. L., \& Walker, A. (2010). Work readiness in graduate recruitment and selection : a review of current assessment methods. Journal of Teaching and Learning for Graduate Employability, 1(1), 13-25. doi:10.21153/jtlge2010vol1no1 art546

Cabellero, C. L., Walker, A., \& FullerTyszkiewicz, M. (2011). The Work Readiness Scale (WRS): Developing a measure to assess work readiness in college graduates. Journal of Teaching and Learning for Graduate Employability, 2(2), 41 - 54. doi: 10.21153/jtlge2011 vol2no1 art552

Carvalho, R. G. G. (2015). Future time perspective as a predictor of adolescents' adaptive behavior in school. School Psychology International, 36(5), 482-497. doi: $10.1177 / 0143034315601167$

Daniels, J., \& Brooker, J. (2014). Student identity development in higher education: implications for graduate attributes and work-readiness. Educational Research, 56(1), 65-76. doi: 10.1080/00131881.2013.874157

Eren, A. (2013). Prospective teachers' perceptions of instrumentality, boredom coping strategies, and four aspects of engagement. Teaching Education, 24(3), 302-326. doi: $10.1080 / 10476210.2012 .724053$
Fong, C. J., \& Kim, Y. W. (2019). A clash of constructs? Re-examining grit in light of academic buoyancy and future time perspective. Current Psychology. doi: 10.1007/s12144-018-0120-4

Froehlich, D. E., Beausaert, S. A. J., \& Segers, M. S. R. (2015). Great Expectations: The Relationship Between Future Time Perspective, Learning from Others, and Employability. Vocations and Learning, 8(2), 213-227. doi: $10.1007 / \mathrm{s} 12186-015-9131-6$

Grashinta, A., Istiqomah, A. P., \& Wiroko, E. P. (2018). Pengaruh Future Time Perspective Terhadap Kematangan Karir Pada Mahasiswa. Jurnal Psikologi Pendidikan \& Konseling: Jurnal Kajian Psikologi Pendidikan dan Bimbingan Konseling, 4(2), 25-31. doi: 10.26858/jpkk.v4i1.4981

Hanani, T., \& Sukirno, S. (2016). Evaluasi kesiapan kerja mahasiswa akuntansi Universitas Negeri Yogyakarta menghadapi era Masyarakat Ekonomi Asean (MEA) 2015. Jurnal Nominal: Barometer Riset Akuntansi dan Manajemen Indonesia, 5(1), 34-53. doi: 10.21831/nominal.v5i1.11475

Hersey, P., \& Blanchard, K. (1996). Great ideas revisited: Revisiting the life-cycle theory of leadership. Training \& Development, 50(1), 42-47.

Hilpert, J. C., Husman, J., Stump, G. S., Kim, W., Chung, W.-T., \& Duggan, M. A. (2012). Examining students' future time perspective: Pathways to knowledge building. Japanese Psychological Research, 54(3), 229-240. doi: 10.1111/j.1468-5884.2012.00525.x

Husman, J., Brem, S. K., Banegas, S., Duchrow, D. W., \& Haque, S. (2015). Learning and Future Time Perspective: The Promise of the Future - Rewarding in the Present. In M. Stolarski, N. 
Fieulaine \& W. van Beek (Eds.), Time Perspective Theory; Review, Research and Application: Essays in Honor of Philip G. Zimbardo (hh. 131-141). doi: 10.1007/978-3-319-07368-2.

Husman, J., \& Hilpert, J. C. (2017). Extending Future Time Perspective Theory through Episodic Future Thinking Research: A Multidisciplinary Approach to Thinking About the Future. Dalam A. Kostić \& D. Chadee (Eds.), Time Perspective: Theory and Practice (hh. 267-280). London: Palgrave Macmillan UK.

Husman, J., Hilpert, J. C., \& Brem, S. K. (2016). Future Time Perspective Connectedness to a Career: The Contextual Effects of Classroom Knowledge Building. Psychologica Belgica, 56(3), 210-225. doi: $10.5334 / \mathrm{pb} .282$

Husman, J., \& Lens, W. (1999). The role of the future in student motivation. Educational Psychologist, 34(2), 113125. doi: 10.1207/s15326985ep3402_4

Husman, J., \& Shell, D. F. (2008). Beliefs and perceptions about the future: A measurement of future time perspective. Learning and Individual Differences, 18(2), 166-175. doi: 10.1016/j.lindif.2007.08.001

Jollands, M., Jolly, L., \& Molyneaux, T. (2012). Project-based learning as a contributing factor to graduates' work readiness. European Journal of Engineering Education, 37(2), 143-154. doi: 10.1080/03043797.2012.665848

Kooij, D. T. A. M., Kanfer, R., Betts, M., \& Rudolph, C. W. (2018). Future time perspective: A systematic review and meta-analysis. Journal of Applied Psychology, 103(8), 867-893. doi: 10.1037/ap10000306
Lang, F. R., \& Carstensen, L. L. (2002). Time counts: Future time perspective, goals, and social relationships. Psychology and Aging, 17(1), 125-139. doi: 10.1037/0882-7974.17.1.125

Lens, W., Paixão, M. P., Herrera, D., \& Grobler, A. (2012). Future time perspective as a motivational variable: Content and extension of future goals affect the quantity and quality of motivation. Japanese Psychological Research, 54(3), 321-333. doi: 10.1111/j.1468-5884.2012.00520.x

Lens, W., \& Seginer, R. (2015). Future Time Perspective and Motivation. In J. D. Wright (Ed.), International Encyclopedia of the Social \& Behavioral Sciences (Second Edition) (pp. 561-566). Oxford: Elsevier.

Maarel, H. V. D. (2011). Occupational future time perspective in the work organization. (Master Thesis).Available from Semantic Scholar Database.

Marliani, R. (2013). Hubungan Antara Religiusitas Dengan Orientasi Masa Depan Bidang Pekerjaan Pada Mahasiswa Tingkat Akhir. Jurnal Psikologi, $\quad$ 9(2), 130-137.doi: 10.24014/jp.v9i2.175

Patterson, E. E. B., Boyd, L., \& Mnatzaganian, G. (2017). The impact of undergraduate clinical teaching models on the perceptions of workreadiness among new graduate nurses: A cross sectional study. Nurse Education Today, 55, 101-106. doi: 10.1016/j.nedt.2017.05.010

Peetsma, T., \& van der Veen, I. (2011). Relations between the development of future time perspective in three life domains, investment in learning, and academic achievement. Learning and Instruction, 21(3), 481-494. doi: 10.1016/j.learninstruc.2010.08.001 
Perry, J. C., Wallace, E. W., \& McCormick, M. P. (2016). Making my future work: evaluation of a new college and career readiness curriculum. Youth \& Society, 50(6), 841-866. doi: $10.1177 / 0044118 X 16658221$

Pool, L. D., \& Sewell, P. (2007). The key to employability: developing a practical model of graduate employability. Education + Training, 49(4), 277-289. doi: 10.1108/00400910710754435

Santrock, J. W. (2012). Life-Span Development (14 th Eds). New York, NY: Mc-Grawhill.

Sersiana, L. (2013). Hubungan antara selfefficacy karir dan persepsi terhadap masa depan karir dengan kematangan karir siswa SMK PGRI Wonoasri tahun ajaran 2012/2013. Jurnal BK UNESA, 3(1). Retrieved from https://jurnalmahasiswa.unesa.ac.id/ind ex.php/jurnal-bkunesa/article/view/3309

Shell, D. F., \& Husman, J. (2001). The multivariate dimensionality of personal control and future time perspective beliefs in achievement and selfregulation. Contemporary Educational Psychology, 26(4), 481-506. doi: 10.1006/ceps.2000.1073
Siegman, A. W. (1961). The relationship between future time perspective, time estimation, and impulse control in a group of young offenders and in a control group. Journal of Consulting Psychology, 25(6), 470-475. doi: 10.1037/h0046829

Walker, T. L., \& Tracey, T. J. G. (2012). The role of future time perspective in career decision-making. Journal of Vocational Behavior, 81(2), 150-158. doi: 10.1016/j.jvb.2012.06.002

Yakhina, Z. S., Yakovlev, S. A., Kozhevnikova, N. V., Nuretdinova, Y. V., \& Solovyeva, N. A. (2016). Practical Recommendations for University Graduates' Readiness Formation to Occupational Mobility. International Journal of Environmental and Science Education, 11(15), 7358$7367 . \quad$ Retrieved from https://ojs.deakin.edu.au/index.php/jtlge /index

Zimbardo, P. G., \& Boyd, J. N. (2015). Putting Time in Perspective: A Valid, Reliable Individual-Differences Metric. In M. Stolarski, N. Fieulaine \& W. van Beek (Eds.), Time Perspective Theory; Review, Research and Application: Essays in Honor of Philip G. Zimbardo (hh. 17-55). doi: 10.1007/978-3-31907368-2 